\title{
The Effectiveness of Footwork Exercises with the HIIT Method in Developing VO2max and Anaerobic Capacity
}

\author{
Donie 1, Yanuar Kiram 2, Hermanzoni 3, Eval Edmizal 4 \\ DOI: $10.35445 /$ alishlah.v13i2.803
}

\begin{abstract}
Article Info
Abstract

Keywords:

Footwork;

VO2max;

Anaerobic;

High-Intensity Interval

Training

The purpose of this study was to determine the development of physiological aspects of increasing aerobic and anaerobic performance in students who become badminton athletes through optimizing footwork exercises using the high-intensity interval method (HITT). This research will provide a solution for trainers in combining and optimizing footwork exercises as a technique in badminton combined with the principles of interval training to increase badminton athletes' aerobic and anaerobic capacity. This study used an experimental approach by giving footwork training treatment (HITT) to 30 Padang State University students who became badminton athletes. Researchers saw the effect of the exercise given on aerobic capacity (VO2max) and anaerobic capacity. The statistical analysis results showed that footwork exercise with The HIIT (High High-Intensity Interval Training) method positively affects badminton athletes' maximal aerobic capacity (VO2max) anaerobic capacity. In this concept, footwork training using the HIIT method effectively develops aerobic and anaerobic metabolism in response to energy requirements during total energy production in training maximum.
\end{abstract}

Kata kunci:

Footwork;

VO2max;

Anaerobic;

High-Intensity Interval

Training

\begin{abstract}
Abstrak
Tujuan dari penelitian ini adalah untuk mengetahui pengembangan aspek fisiologis peningkatan kinerja aerobik dan anerobik pada mahasiswa yang menjadi atlet bulutangkis melalui optimalisasi latihan footwork dengan menggunakan metoda interval dengan intensitas tinggi (HITT). Penelitian ini akan memberikan solusi bagi pelatih dalam mengkombinasikan dan mengoptimalkan latihan footwork sebagai teknik dalam bulutangkis yang dikombinasi dengan prinsip-prinsip latihan interval akan memberikan sumbangan terhadap meningkatkan kapasitas aerobik dan anaerobik atlet bulutangkis. Penelitian ini menggunakan pendekatan eksperimen dengan memberikan perlakuan latihan footwork dengan metoda (HITT) kepada 30 mahasiswa Universitas Negeri Padang yang menjadi atlet bulutangkis. Peneliti melihat pengaruh dari latihan yang diberikan terhadap kapasitas aerobik (VO2max) dan kapasitas anaerobik. Hasil analisis statistik menunjukan bahwa latihan footwork dengan metode HIIT (High Intensity Interval Training) memiliki efek positif pada peningkatan kapasitas aerobik maksimal $\left(\mathrm{VO}_{2 \max }\right)$ dan
\end{abstract}

\footnotetext{
${ }^{1}$ Universitas Negeri Padang, Padang, Indonesia Email: donie17@fik.unp.ac.id

2 Universitas Negeri Padang, Padang, Indonesia

Email: yanuarkiram@fik.unp.ac.id

3 Universitas Negeri Padang, Padang, Indonesia

Email: hermanzoni_fik@yahoo.com

4 Universitas Negeri Padang, Padang, Indonesia

Email: evaledmizal@fik.unp.ac.id
} 
kapasitas anerobik atlet bulutangkis. Dalam konsep ini latihan footwork dengan metode HIIT efektif mengembangkan metabolisme aerobik dan anaerobik dalam menanggapi kebutuhan energi, selama produksi energi total dalam latihan maksimal yang berlangsung.

\section{INTRODUCTION}

Badminton is the fastest racket sport globally; badminton athletes' smash speeds can approach $100 \mathrm{~m} / \mathrm{s}$, and the average shuttle speed throughout a match is between 50 and $75 \mathrm{~m} / \mathrm{s}$ (Ooi et al., 2009). Because badminton is the fastest racquet sport, the athlete's physical capacity is crucial. The physical capacity needs of athletes are an essential component of badminton sporting performance (Rankovi et al., 2010). The fundamental physiological measure of physical activity, aerobic capacity (VO2max), is a powerful predictor of health and performance (LangeskovChristensen et al., 2015). Aerobic work capacity can grow more quickly and faster (Hickson et al., 1977).

Athletes' physical condition is one of the determinants of their excellent performance. One of the components of a necessary physical condition in sports is cardiorespiratory endurance. The maximum oxygen consumption (VO2max) can be used to assess cardiorespiratory endurance for aerobic capacity (Rusdiana, 2020; Subarjah, 2016). Physiological testing of elite athletes necessitates the accurate identification and assessment of a sport's underlying components. It is now widely accepted that maximal oxygen uptake (VO2max) determines long-term performance. Because VO2max defines the upper limit of the aerobic route, this ability is further described as endurance and, more specifically, aerobic endurance. It must be separated from endurance ability or performance endurance, which are synonymous with badminton performance. This review looks at the various approaches for determining aerobic endurance that has been published in the literature (Bosquet et al., 2002).

In both submaximal and maximal intensity, anaerobic capacity is the main activity. The functioning of the circulatory and respiratory systems and morphological state, metabolism, muscle structure, and other factors all influenced it (Pavlovic, 2016). Furthermore, anaerobic capacity is the most significant quantity of adenosine triphosphate that may be resynthesized during maximal activity using anaerobic metabolism (both lactic and lactic systems). (Minahan et al., 2007).

Milanovic (2015) researched the use of HIIT (High-Intensity Interval Training) to determine the effectiveness of HIIT and continuous resistance training for raising VO2max. Festiawan (2020) investigated the impact of High-Intensity Interval Training (HIIT) and Fartlek Training on Athlete Sudirman Expedition VII's VO2 Max level. Several previous research haven't looked into the role of exercise in improving badminton athletes' VO2max and anaerobic capacity. The researcher examines HIIT-style footwork activities in this section. As proven by extensive reviews that have marked interval training from a performance enhancement standpoint, exercise programs are quite complicated and incorporate numerous variables that may be changed from workout intensity, duration, and frequency (Marques, 2017; Seiler, 2010). Interval training is simply defined as intervals of intense training followed by rest periods (Foxet al. 1973).

Interval training consists of a series of relatively intense activities separated by short (specified) recuperation intervals. This method is classified as high-intensity interval training (HIIT; near maximal effort) by a recognized classification methodology (MacInnis \& Gibala, 2017). Short-intensity exercise is alternated with recovery intervals of passive or light-intensity movement in high-intensity interval training (HIIT) (Roy, 2013).

One of the short-intensity exercises is footwork, which can be done using the HITT (HighIntensity Interval Training) approach. Conditioning training frequently employs high-intensity interval training (HIIT). This is the process of creating training programs that are both important and effective for athletes to promote physiological adaptations that lead to improved physical 
performance (Guiraud et al., 2012). Furthermore, new research reveals that HIIT is more fun than ongoing moderate-intensity training. (Buchheit \& Laursen, 2013).

In this context, the researchers wanted to see if a training program incorporating periods of high intensity (90 percent) exercise may significantly improve VO2max and anaerobic capacity in all subjects. The basic premise of our study is that physiological adaptability to VO2max and anaerobes should be assessed using an exercise that maximizes physiological adaptation. (Hickson et al., 1977).

When compared to traditional continuous exercise, this study aims to learn more about the idea that periods of footwork exercise using the HIIT (High-Intensity Interval Training) method may be more effective and efficient in producing maximal aerobic capacity (VO2max) and anaerobic capacity development (Bacon et al., 2013). It is crucial for badminton athletes to understand and apply to get the most out of their training.

\section{METHODS}

This study uses an experimental one-group pretest and posttest design (Cobb et al., 2003). A total of 30 Padang State University students, badminton athletes aged 18 to 20, participated in this study. A maximal aerobic capacity test (VO2max), a Bleeb Test, and an anaerobic capacity test are used in this study (sprinting 30 meters). The following are the procedures used in this study:

1) Intervention Procedure

A total of 30 athletes competed in one group. For six weeks, the study was placed on the badminton court at Padang State University (treatment was given three times a week) (18 meetings).

2) Observer Reliability

Two raters assessed each athlete separately (badminton coaches). The raters were not asked to test the experimental circumstances in any way. Only a number identifies each athlete. Each observer recorded the time and scored the athlete's maximum aerobic capacity (VO2max) and anaerobic capacity on a standard score sheet. To assure rater reliability, assessors are educated using a stock watch as an example, and each athlete is given one rating sheet per trial. After seeing 30 athletes on the first day and evaluating the same 30 on the second day, intra-rater reliability was tested.

The data was statistically analyzed using the SPSS version 24 application. The 0.05 level of significance was used to determine significance. The data were tested for a variance before being examined, with the Kolmogorov-Smirnov test (KS test) on the normality test of the variables and the covariance matrix equality test and homogeneity test. A non-significant value (p o.05) meant that the data did not depart significantly from the multivariate variables' normality, allowing parametric tests to be used.

\section{FINDINGS AND DISCUSSION}

The difference in VO2max and anaerobic capacity of badminton competitors before and after HIIT (High-Intensity Interval Training) footwork training was the main effect in this study. It can be concluded, based on the exercises provided in the previous results, that:

Table 1. Tests of Normality

\begin{tabular}{lllllll}
\hline & \multicolumn{3}{l}{ Kolmogorov-Smirnov(a) } & \multicolumn{2}{l}{ Shapiro-Wilk } & \\
\cline { 2 - 7 } & Statistic & df & Sig. & Statistic & df & Sig. \\
\hline Before_VO2max & .156 & 30 & .061 & .973 & 30 & .615 \\
After_VO2max & .085 & 30 & $.200\left(^{*}\right)$ & .983 & 30 & .888 \\
Before_Anerobik & .144 & 30 & .112 & .951 & 30 & .177 \\
After_Anerobik & .114 & 30 & $.200(*)$ & .964 & 30 & .395 \\
\hline
\end{tabular}

* This is a lower bound of the true significance.

a Lilliefors Significance Correction 
The following is the result: Statistical prices for VO2max capacity and Anaerobic capacity of badminton athletes before being provided footwork workouts utilizing the HIIT method were 0.085 and 114 and sig or p-value $=0.200>0.05$ for Kolmogorov-Smirnov, Ho was approved or not significant. As a result, the statistics on badminton athletes' VO2max capacity and anaerobic capacity are typically distributed. See the usual Quantile and Quantile (Q-Q) plot diagram for further information.

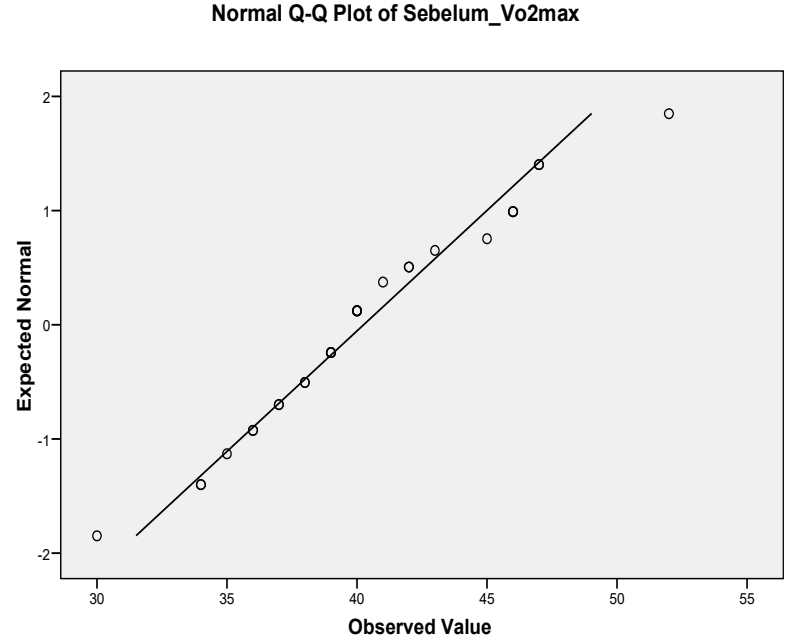

Normal Q-Q Plot of Sebelum_Anerobik

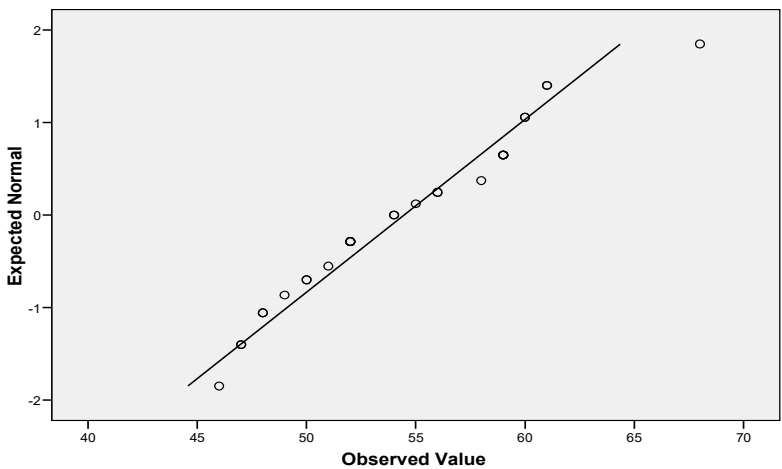

Normal Q-Q Plot of Setelah Vo2max

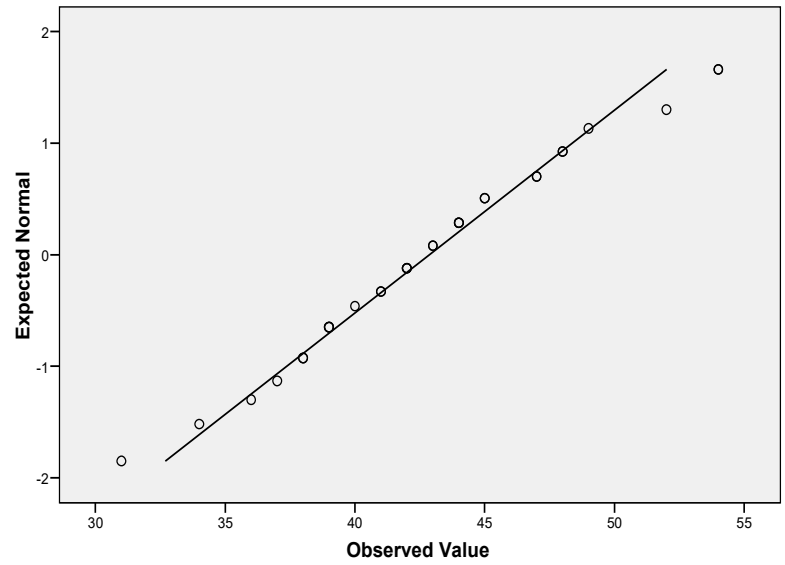

Normal Q-Q Plot of Setelah_Anerobik

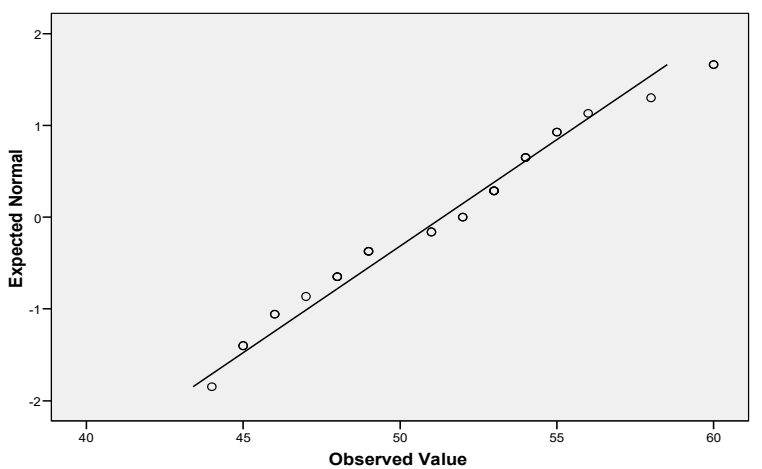

Figure 1. Normal Quantile and Quantil (Q-Q) plot Before and After

The normality test of the VO2max and Anaerobic capacity data can also be viewed from the Detrended Normal Q-Q Plot, in addition to the normal Q-Q Plot. If the data distribution in the form of dots does not create a distinctive pattern and gathers around a horizontal line across the zero points, the data is said to be broadly distributed.

Table 2. Test of Homogeneity of Variance

\begin{tabular}{llllll}
\hline & & Levene & \multirow{2}{*}{ df1 } & df2 & Sig. \\
\hline \multirow{4}{*}{ Data } & Based on Mean & .810 & 3 & 116 & .491 \\
& Based on Median & .832 & 3 & 116 & .479 \\
& Based on Median and with adjusted & .832 & 3 & 110.777 & .479 \\
& df & .799 & 3 & 116 & .497 \\
\hline
\end{tabular}

Lavene statistic test based on all criteria with sig value is all above 0.05. Because of the value of sig $>0.05$. It can be concluded that the variables Y1 and Y2 come from a homogeneous population. 
Table 3. Paired Samples Statistics

\begin{tabular}{llllll}
\hline & & Mean & $\mathrm{N}$ & Std. Deviation & Std. Error Mean \\
\hline \multirow{2}{*}{ Pair 1 } & Vo2max & 40.27 & 30 & 4.734 & .864 \\
\multirow{2}{*}{ Pair 2 } & Ane2max & 42.87 & 30 & 5.507 & 1.005 \\
& Anerobik & 54.47 & 30 & 5.348 & .976 \\
\hline
\end{tabular}

The Paired Sample Statistics table shows that before receiving HIIT footwork training, badminton athletes' average VO2max and anaerobic capacity were 40.27 for VO2max and 44.47 for anaerobic capacity, with standard deviations of 4.734 for VO2max and 5.384 for anaerobic capacity. Furthermore, 42.87 for VO2max capacity and 51.37 for anaerobic capacity were obtained after being administered footwork using the HIIT method, with a standard deviation of 5.507 for VO2max 4,311 for anaerobic capacity. It suggests a statistically significant difference in average VO2max and anaerobic capacity before and after HIIT (High-Intensity Interval Training) footwork workouts.

\section{Tabel 4. Paired Samples Correlations}

\begin{tabular}{lllll}
\hline & & $\mathrm{N}$ & Correlation & Sig. \\
\hline Pair 1 & Vo2max \& Vo2max & 30 & .917 & .000 \\
Pair 2 & Anerobik \& Anerobik & 30 & .964 & .000 \\
\hline
\end{tabular}

The correlation coefficient of the athlete's VO2max and anaerobic capacity scores before and after being given footwork with the HIIT method is 0.917 for VO2max capacity and 0.964 for anaerobic capacity with sig. or p-value $=0.000$ and 0.0000 .917 and 0.964 for VO2max and anaerobic capacity with sig. or p-value $=0.000$ and 0.0000 .917 and 0.964 for VO.

Table 5. Paired Samples Test

\begin{tabular}{|c|c|c|c|c|c|c|c|c|c|}
\hline & & \multicolumn{5}{|c|}{ Paired Differences } & \multirow{3}{*}{$\mathrm{t}$} & \multirow{3}{*}{$\mathrm{df}$} & \multirow{3}{*}{$\begin{array}{l}\text { Sig. } \\
\text { (2- } \\
\text { tailed } \\
\text { ) }\end{array}$} \\
\hline & & \multirow[t]{2}{*}{ Mean } & \multirow{2}{*}{$\begin{array}{l}\text { Std. } \\
\text { Deviatio } \\
\mathrm{n}\end{array}$} & \multirow{2}{*}{$\begin{array}{l}\text { Std. } \\
\text { Error } \\
\text { Mean }\end{array}$} & $\begin{array}{l}95 \% \\
\text { Interval } \\
\text { Difference }\end{array}$ & $\begin{array}{l}\text { Confidence } \\
\text { of the }\end{array}$ & & & \\
\hline & & & & & Upper & Lower & & & \\
\hline Pair 1 & $\begin{array}{l}\text { Vo2max - } \\
\text { Vo2max }\end{array}$ & $\begin{array}{l}- \\
2.60 \\
0\end{array}$ & 2.222 & .406 & -3.430 & -1.770 & 6.409 & 29 & .000 \\
\hline Pair 2 & $\begin{array}{l}\text { Anerobik } \\
- \\
\text { Anerobik }\end{array}$ & 3.100 & 1.647 & .301 & 2.485 & 3.715 & $\begin{array}{l}10.30 \\
7\end{array}$ & 29 & .000 \\
\hline
\end{tabular}

In the Paired Samples Test table, the difference in mean $=2,600$ and 3,100 is the difference in the VO2max and Anaerobic capacity scores of badminton athletes after and before being given footwork training HIIT method. The positive value was significant after being given footwork training with the HIIT method with a higher VO2max and anaerobic capacity score for badminton athletes than before being given footwork training with the HIIT method. Furthermore, this table also obtained std. error Mean, which shows the standard error number of the average difference. Furthermore, the most important results from this table are the statistical prices $t=6.409$ for VO2max capacity and $\mathrm{t} 3715$ for the anaerobic capacity of badminton athletes, with $\mathrm{db}=29$ and sig p-value $=0.000<0.05$ or Ho is rejected. Thus, it was concluded that there was a significant difference in the VO2max capacity and the anaerobic capacity of badminton athletes before and after being given footwork training using the HIIT (High-Intensity Interval Training) method.

Footwork exercise using the HIIT (High-Intensity Interval Training) method is an effective and time-efficient training method to induce both central (cardiovascular) adaptation and peripheral (skeletal muscle) adaptation associated with improving health. HIIT (High-Intensity 
Interval Training) can develop the maximum aerobic capacity (VO2max) of badminton athletes (Vidiari J et al., 2017). It can also improve the anaerobic ability of badminton athletes.

This high-intensity exercise allows individuals to exercise for more extended periods with a more significant percentage of their VO2max (Joyner \& Coyle, 2008). High-intensity workloads during training sessions have traditionally been used to train athletes who require maximal aerobic (VO2max) and anaerobic capacity (Cornish et al., 2011).

It should be highlighted that comparing HIIT forms with equivalent (and maximal) cardiorespiratory responses can result in significantly varied anaerobic energy outputs, demonstrating the need to account for the diverse physiological responses to HIIT. Maximum oxygen uptake (VO2max) up to 100 percent of your maximum running speed is required for minimum/power. (Buchheit \& Laursen, 2013).

While much of the work done to date has involved relatively high volume protocols comparable to traditional resistance training volumes, HIIT has been shown to improve cardiorespiratory fitness related to maximal aerobic capacity (VO2max) in various populations including badminton (Gibala et al., 2012; Moholdt et al., 2009; Munk et al., 2009). In most cases, the improvement in cardiorespiratory fitness after HIIT is better than after sustained moderateintensity training (Gibala et al., 2012; Wright et al., 2007).

In terms of raising VO2max, quality of life, and metabolic health, high-intensity interval training can give badminton athletes the same or higher benefits as weight training (Kramps \& Lane-Cordova, 2021). In badminton athletes, we found that utilizing the HIIT method to improve footwork can improve muscle strength and respiratory fitness related to maximal aerobic capacity (VO2max). A 12-week protocol consisting of three 12-minute sessions each week would improve badminton athletes' VO2max and anaerobic capacity. (Bhatia \& Kayser, 2019; Javiera Abarzúa et al., 2019; Martland et al., 2020; Sawyer et al., 2020).

In various forms of training, the current HIIT format is one of the most effective ways to improve cardiorespiratory and metabolic function and, in turn, can improve the physical performance of athletes (Biddle \& Batterham, 2015). In addition, high-intensity interval training (HIIT) produces adaptations similar to resistance training (Pugh et al., 2015).

Because high-intensity exercise appears to play a crucial function in ventilation management, re-examining that footwork exercise using the HIIT (High-Intensity Interval Training) approach can generate conditions in which $\mathrm{CO} 2$ production is increased (Milsom et al 2004). It will have an indirect effect on athletes' aerobic and anaerobic capability. HIIT can be a direct way for badminton players to increase their aerobic and anaerobic capacity. (Cao et al., 2019).

\section{CONCLUSION}

Footwork activities combined with HIIT (High-Intensity Interval Training) have increased maximal aerobic capacity (VO2max) and anaerobic capacity. This study did not include physical labor, but it did reveal that extremely short bouts of high-intensity exercise followed by a more extended recuperation period can significantly impact exercise capacity. This follow-up study might be carried out to provide new evidence regarding footwork workouts using the HIIT approach for further research.

\section{REFERENCES}

Bacon, A. P., Carter, R. E., Ogle, E. A., \& Joyner, M. J. (2013). VO2max Trainability and HighIntensity Interval Training in Humans: A Meta-Analysis. PLoS ONE. https://doi.org/10.1371/journal.pone.0073182

Bhatia, C., \& Kayser, B. (2019). Preoperative high-intensity interval training is effective and safe in deconditioned patients with lung cancer: A randomized clinical trial. Journal of Rehabilitation Medicine. https://doi.org/10.2340/16501977-2592

Biddle, S. J. H., \& Batterham, A. M. (2015). High-intensity interval exercise training for public health: A big HIT or shall we HIT it on the head? International Journal of Behavioral Nutrition and Physical Activity. https://doi.org/10.1186/s12966-015-0254-9 
Bosquet, L., Léger, L., \& Legros, P. (2002). Methods to determine aerobic endurance. In Sports Medicine. https://doi.org/10.2165/00007256-200232110-00002

Buchheit, M., \& Laursen, P. B. (2013). High-intensity interval training, solutions to the programming puzzle: Part II: Anaerobic energy, neuromuscular load and practical applications. In Sports Medicine. https://doi.org/10.1007/s40279-013-0066-5

Cao, M., Quan, M., \& Zhuang, J. (2019). Effect of high-intensity interval training versus moderateintensity continuous training on cardiorespiratory fitness in children and adolescents: A meta-analysis. In International Journal of Environmental Research and Public Health. https://doi.org/10.3390/ijerph16091533

Cobb, P., Confrey, J., Disessa, A., Lehrer, R., \& Schauble, L. (2003). Design Experiments in Educational Research. Educational

Researcher. https://doi.org/10.3102/0013189X032001009

Cornish, A. K., Broadbent, S., \& Cheema, B. S. (2011). Interval training for patients with coronary artery disease: A systematic review. In European Journal of Applied Physiology. https://doi.org/10.1007/s00421-010-1682-5

Festiawan, R., Suharjana, S., Priyambada, G., \& Febrianta, Y. (2020). Highintensity interval training dan fartlek training: Pengaruhnya terhadap tingkat VO2 Max. Jurnal

Keolahragaan, 8(1), 9-20. doi:https://doi.org/10.21831/jk.v8i1.31076

Gibala, M. J., Little, J. P., Macdonald, M. J., \& Hawley, J. A. (2012). Physiological adaptations to low-volume, high-intensity interval training in health and disease. Journal of Physiology. https://doi.org/10.1113/jphysiol.2011.224725

Guiraud, T., Nigam, A., Gremeaux, V., Meyer, P., Juneau, M., \& Bosquet, L. (2012). High-intensity interval training in cardiac rehabilitation. In Sports Medicine. https://doi.org/10.2165/11631910-000000000-00000

Hickson, R. C., Bomze, H. A., \& Holloszy, J. O. (1977). Linear increase in aerobic power induced by a strenuous program of exercise. J.APPL.PHYSIOL.RESPIR.ENVIRON.EXERCISE_PHYSIOL. https://doi.org/10.1152/jappl.1977.42.3.372

Javiera Abarzúa, V., Williams Viloff, C., Javiera Bahamondes, V., Yeritza Olivera, P., Poblete-Aro, C., Herrera-Valenzuela, T., Oliva, C., \& García-Díaz, D. F. (2019). High intensity interval training in teenagers. Revista Medica de Chile. https://doi.org/10.4067/soo3498872019000200221

Joyner, M. J., \& Coyle, E. F. (2008). Endurance exercise performance: The physiology of champions. In Journal of Physiology. https://doi.org/10.1113/jphysiol.2007.143834

Kramps, K., \& Lane-Cordova, A. (2021). High-intensity interval training in cardiac rehabilitation. In Sport Sciences for Health. https://doi.org/10.1007/s11332-021-00731-0

Langeskov-Christensen, M., Heine, M., Kwakkel, G., \& Dalgas, U. (2015). Aerobic Capacity in Persons with Multiple Sclerosis: A Systematic Review and Meta-Analysis. In Sports Medicine. https://doi.org/10.1007/s40279-015-0307-x

Milanović Z, Sporiš G, Weston M. Effectiveness of High-Intensity Interval Training (HIT) and Continuous Endurance Training for VO2max Improvements: A Systematic Review and MetaAnalysis of Controlled Trials. Sports Med. 2015 Oct;45(10):1469-81. doi: 10.1007/s40279015-0365-0. PMID: 26243014.

MacInnis, M. J., \& Gibala, M. J. (2017). Physiological adaptations to interval training and the role of exercise intensity. In Journal of Physiology. https://doi.org/10.1113/JP273196

Marques, M. C. (2017). Training programming: Revisiting terminology. In Motricidade. https://doi.org/10.6063/motricidade.13445

Martland, R., Mondelli, V., Gaughran, F., \& Stubbs, B. (2020). Can high-intensity interval training improve physical and mental health outcomes? A meta-review of 33 systematic reviews across the lifespan. Journal of Sports Sciences. https://doi.org/10.1080/02640414.2019.1706829

Minahan, C., Chia, M., \& Inbar, O. (2007). Does power indicate capacity? 30-S wingate anaerobic test vs. maximal accumulated $\mathrm{O} 2$ deficit. International Journal of Sports Medicine. https://doi.org/10.1055/s-2007-964976 
Moholdt, T. T., Amundsen, B. H., Rustad, L. A., Wahba, A., Løvø, K. T., Gullikstad, L. R., Bye, A., Skogvoll, E., Wisløff, U., \& Slørdahl, S. A. (2009). Aerobic interval training versus continuous moderate exercise after coronary artery bypass surgery: A randomized study of cardiovascular effects and quality of life. American Heart Journal. https://doi.org/10.1016/j.ahj.2009.10.003

Munk, P. S., Staal, E. M., Butt, N., Isaksen, K., \& Larsen, A. I. (2009). High-intensity interval training may reduce in-stent restenosis following percutaneous coronary intervention with stent implantation. A randomized controlled trial evaluating the relationship to endothelial function and inflammation. American Heart Journal. https://doi.org/10.1016/j.ahj.2009.08.021

Ooi, C. H., Tan, A., Ahmad, A., Kwong, K. W., Sompong, R., Ghazali, K. A. M., Liew, S. L., Chai, W. J., \& Thompson, M. W. (2009). Physiological characteristics of elite and sub-elite badminton players. Journal of Sports Sciences. https://doi.org/10.1080/02640410903352907

PAVLOVIC, R. (2016). Fatique Index - Indicator of Anerobic Abilities Students. International Journal of Science Culture and Sport. https://doi.org/10.14486/intjscs522

Pugh, J. K., Faulkner, S. H., Jackson, A. P., King, J. A., \& Nimmo, M. A. (2015). Acute molecular responses to concurrent resistance and high-intensity interval exercise in untrained skeletal muscle. Physiological Reports. https://doi.org/10.14814/phy2.12364

Ranković, G., Mutavdžić, V., Toskić, D., Preljević, A., Kocić, M., Nedin-Ranković, G., \& Damjanović, N. (2010). Aerobic capacity as an indicator in different kinds of sports. Bosnian Journal of Basic Medical Sciences. https://doi.org/10.17305/bjbms.2010.2734

Roy, B. A. (2013). High-Intensity Interval Training. ACSM's Health \& Fitness Journal. https://doi.org/10.1249/fit.obo13e31828cb21c

Rusdiana, A. (2020). Analysis Differences of VO2max between Direct and Indirect Measurement in Badminton, Cycling and Rowing. International Journal of Applied Exercise Physiology.

Sawyer, A., Cavalheri, V., \& Hill, K. (2020). Effects of high intensity interval training on exercise capacity in people with chronic pulmonary conditions: A narrative review. In BMC Sports Science, Medicine and Rehabilitation. https://doi.org/10.1186/s13102-020-00167-y

Seiler, S. (2010). What is best practice for training intensity and duration distribution in endurance athletes? In International Journal of Sports Physiology and Performance. https://doi.org/10.1123/ijspp.5.3.276

Subarjah, H. (2016). The effect of motor skills and Vo2 max to the achievement in playing badminton. Man in India.

Vidiari J, I., Adiatmika, I. P. G., Indah S.H. Adiputra, L. M., Tirtayasa, K., Muliarta, M., \& Griadhi, A. (2017). High Intensity Interval Training (HIIT) Lebih Meningkatkan Ambang Anaerobik Daripada Steady State Training Pada Siswa Anggota Kelompok Ekstrakurikuler Atletik Lari Jarak Pendek. Sport and Fitness Journal. https://doi.org/10.24843/spj.2017.v05.io3.po9

Wright, D. C., Han, D. H., Garcia-Roves, P. M., Geiger, P. C., Jones, T. E., \& Holloszy, J. O. (2007). Exercise-induced mitochondrial biogenesis begins before the increase in muscle PGC-1 $\alpha$ expression. Journal of Biological Chemistry. https://doi.org/10.1074/jbc.M606116200 